\title{
Detection on Momentous Robust Impact of Stock Price among All Sectors in Bursa Malaysia towards COVID-19 Pandemic Daily Announcement News
}

\author{
Noriza Mohd Saad ${ }^{1}$, Nor Edi Azhar Mohamad ${ }^{2}$ \\ ${ }^{1,2}$ Universiti Tenaga Nasional, Muadzam Shah, Pahang malaysia \\ ${ }^{1}$ Noriza@uniten.edu.my, ${ }^{2}$ NorEdi@uniten.edu.my
}

\begin{abstract}
There is twofold of the study aim: (1) To investigate the reaction trends of stock price in Main Market towards COVID-19 spreads in Malaysia. (2) To investigate the relationship between share price with number of confirmed case of COVID-19 in Malaysia.

This study was tested the reaction of share price based on event study approach and investigate the relationship between share price and COVID19 using multiple regression approach. Therefore, random effect robust regression model was applied to tackle the dynamic changes in price of stock since the movement is based on daily basis. In Overall, the finding shows that more than half of the sectors' share price are significant as shown by panel A and have a relationship towards the number of COVID cases for instance, construction, consumer product and services, energy, industrial products \& services, property, technology, telecommunication \& media and transportation \& logistic sector with all indicate negatively association. Meaning that, the higher the number of COVID cases, the lower the share price performance.
\end{abstract}

Index Terms

COVID-19; Share Price; Robust, Sector, Malaysia

Article Received: 10 August 2020, Revised: 25 October 2020, Accepted: 18 November 2020

\section{Introduction}

The novel coronavirus (COVID-19) represents a fearsome risk which is stirring feverish behaviour by investors worldwide include in Malaysia. According to the World Health Organization (WHO), by 10 March 2020, COVID-19 had led to more than 110,000 confirmed infections and 4,015 deaths in 110 countries and the numbers are increasing rapidly. Due to this extremely and drastically increasing in figure, the WHO declare the COVID-19 as pandemic spreads. Following to that, the increasing pattern of this COVID-19 was shown statistically by Worldometers website on 26th October 2020, whereby there are $43,374,933$ confirmed infections and $1,159,472$ deaths in 215 countries. As of the date, there are 26,565 confirmed cases in Malaysia, with 229 deaths reported by Ministry of Health Malaysia.

The COVID-19 pandemic was first identified to have spread to Malaysia on 25 January 2020. Reported by Malaysiakini news based on source from Ministry of Health Malaysia, the number of COVID-19 remained relatively low until a large spike in cases in March 2020, however within a few weeks after, Malaysia had become the country with the highest cumulative number of confirmed COVID-19 infections in South East Asia (in end of March, 2020) and in midst of April, 2020 the daily confirmed cases shows a decreasing pattern for instance; as of 19th and 20th April 2020, there are only 84 and 36 new confirmed cases in the country respectively (see figure 1). Until the study period, in August 2020 the number of the COVID -19 cases are in decreasing rate.

Beginning from 15 March, Malaysia saw a significant jump in active cases. The Prime Minister of Malaysia held a live nationwide telecast on 16 March 2020 at 10:00PM to announce the decision of the federal government in implementing the Movement Control Order (MCO). With the MCO put in place since 18 March 2020, all citizens have been prohibited from leaving the country with foreigners also prohibited from entering the country. In a statement to StarBiz, Bursa Malaysia said the Covid-19 pandemic has evolved from being health issue to potentially becoming a source of serious economic challenge. In early March, the FBM KLCI along with global markets went through a roller coaster ride, with most markets registering sharp decline of between $20 \%$ to $30 \%$ following the first fallout from the Covid-19 virus. Consequences of COVID-19, stock market players issue their quick responds on how this virus affect the business performance whereby most of the affected sectors are airlines, tourism, hotels, transportation and many more. Otherwise, some of the company performed better or still active in their trading at Bursa during this situation due to product offer received a high demand such as medicines and pharmaceutical and medical company, utility, information technology services, food and services, gas and water and so on.

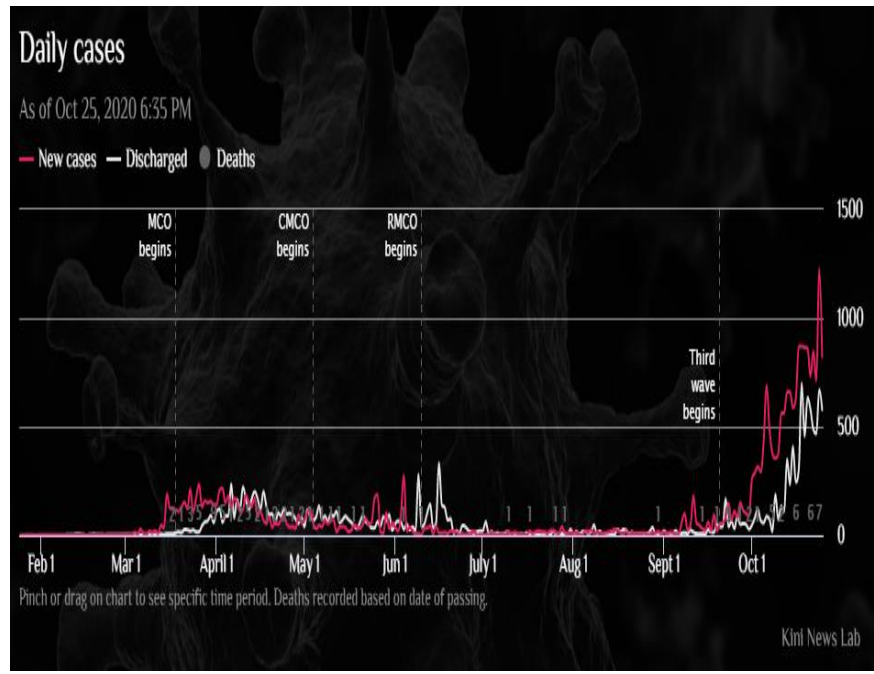

Figure 1: The graph of daily confirmed cases of COVID-19 in Malaysia 
Source: Malaysiakini stats, retrieved on 26th October 2020 With this news or announcement on the restrictions especially no. 3 and no. 6 as highlighted above, majority of the stock market player issue their quick responds towards their trading performance that affect the stock price. They also realize that the stock market performance is globally affected by this COVID-19 pandemic spreads.

With the MCO put in place since 18 March 2020 all citizens have been prohibited from leaving the country with foreigners also prohibited from entering the country. Consequences of COVID-19, stock market players issue their quick responds on how this virus affect the business performance whereby most of the affected sectors are airlines, tourism, hotels, transportation and many more. Otherwise, some of the company performed better or still active in their trading at Bursa during this situation due to product offer received a high demand such as medicines and Pharmaceuticals Company, utility, information technology services, food and services, gas and water and so on.

In parallel with the Malaysian government announcement on the MCO, some of the listed companies' share price is affected. In a joint statement, the Securities Commission and Bursa Malaysia said it is important for the markets to remain open, as closing the markets would neither mitigate nor address the underlying causes of market volatility. The regulators said they would maintain continuous trading and market operation, to facilitate investors to manage their risks and opportunities [1].

Therefore, since our both stock market regulators still encourage the stock market remain open and believe that the investors can diversified their portfolio towards risk and opportunities, that means some of the sectors are underperformed but some of them is outperformed. With respect to that issues, this study is motivated to detect on momentous impact of stock price reaction towards Covid-19 pandemic daily announcement news based on event study approach in Malaysia.

Thus, next sections discuss on the issues arise on how the stock price react towards number of confirmed cases of COVID-19 in Malaysia based on new assumptions. Follows by data and methodology, results and policy implications towards existing government policies compliance by securities commissions and Bursa Malaysia as well as and future regulatory and action need to be taken to facing such pandemic spreads.

\section{Literature Review}

Bursa Malaysia and other emerging stock markets will likely remain a laggard until June 2020, partly due to the outbreak of the COVID-19. The regional markets would be extremely weighed down if the deadly COVID-19 prolonged. Foreign investors had taken a cautious stance on Bursa particularly, amid the negative headlines emanating from China, they added. Bursa's benchmark FTSE Bursa Malaysia KLCI (FBM KLCI) index ended mixed yesterday amid profit-taking in heavyweights and bargain hunting in small-cap stocks as global markets continued to face uncertainties. The index fell 1.17 points to $1,550.47$ from Tuesday's close of 1,551.64[2]. In an interconnected world, domestic confidence is not usually enough. Well run and profitable companies' prices on stock exchanges will adjust accordingly based on the external environments

Stocks on Malaysia's stock exchange of Bursa Malaysia tumbled during the outbreak as investors sold securities due to the expected economic impact caused by the COVID-19, which along with other emerging stock markets are predicted to remain until June 2020 With China as Malaysia's largest trading partner, the country's economy was directly impacted and economic experts have warned the prolonged virus outbreak could hit the country gross domestic product (GDP) hard.

The country's economic growth may fall below 4\% if the coronavirus outbreak worsens and powerhouses like China and the US fail to halt the slides of their own economies. Countries across the world are already calculating the billions of losses due to the Covid-19 which is the worst flu outbreak in 18 years. Trade-reliant economies like South Korea, Singapore and Malaysia would be severely impacted. The three countries had already felt the impact of the USChina trade war. China is Malaysia's largest trading partner and the cooling of the second-largest economy in the world would definitely impact the country. The spread of the Covid-19, hits exports, factory output and tourism. A Bloomberg poll of 33 economists estimated Malaysia's average growth of $4.2 \%$ with individual forecasts ranging between $3.7 \%$ and $4.7 \%$. One analyst expects the coronavirus will hive $0.4 \%$ of Malaysia's GDP [4].

Furthermore, China daily on 19 February 2020 reported that Malaysia which also largely relied on tourism and being among the top destinations for Chinese tourists, suffered a stark decline of tourist arrival from Mainland China due to the outbreak with the tourism industry hit hardest; costing around RM3.37 billion losses until March. Malaysian states highly dependent on tourism sectors and being the point for Mainland Chinese visitors such as Johor [5] Malacca [6], Penang [7] and were among the heaviest affected with hotel bookings and food stalls have reported large loss in businesses These subsequently forced the states to shift their focus to the Southeast Asian market due to the decline of Mainland Chinese tourists [8][9].

Regardless the large losses incurred by tourism businesses, a number of Malaysians have voiced their concerns over the spread of the virus and urging a ban on travellers from China to the country with some 149,000 in support of the call [10][11]. Aberdeen Standard Investments of Malaysia also predicted the country currency of Malaysian ringgit (MYR) to weaken further throughout the local and worldwide outbreak which exacerbate further by instable local political scene in the country [12].

In china, studied about the market performance as proxy by share price changes and response trends of Chinese industries to the COVID-19 pandemic. Their findings stated that transportation, mining, electricity \& heating, and environment industries have been adversely impacted by the pandemic. However, manufacturing, information technology, education and health-care industries have been resilient to the pandemic [13].

In Vietnam, the impact of the COVID-19 lockdown on stock market performance was found that there is an adverse impact of the daily increasing number of COVID-19 cases on stock returns whereby the financial sector was hardest hit on the Vietnam stock market during the COVID-19 outbreak [14]. 
In United States, COVID-19 outbreak showed a big impact on energy prices and stock market performance besides weakening in crude oil price. They concluded that the COVID-19 has a significant impact on the global economy since their study covers crude oil price and three US stock indexes: DJI, S\&P 500, and NASDAQ Composite [15].

Further analysis of the US where changes in share prices allow us to see how different industries are affected by COVID-19 in real-time/daily basis. Stock market data does have a few limitations however, when it comes to measuring the impact of the crisis [16]. Notably it does not include small firms, firms which are not publicly listed, the third sector or the public sector, which might be affected quite differently. For example, many public sector services have seen an increase in demand. In addition, many of these firms operate internationally, so changes in their share prices will represents the effects not only on the UK economy but also in other markets that they operate in. Finally, other factors may also have affected share prices.

The spread of COVID-19, and international measures to contain it, are having a major impact on economic activity in the UK. In this observation we describe how this impact has varied across industries using data on share prices of firms listed on the London Stock Exchange, and how well targeted government support for workers and companies is in light of this. This follows [17] who describe the impact on the US and China by looking at changes in share prices. The industries that have been hardest hit include tourism and leisure (which includes air travel), fossil fuels production and distribution, insurance, retailers (excluding food and drug retailers) and some large manufacturing industries. At the other end of the spectrum some industries have outperformed the market, including food and drug manufacturers and retailers, utilities, high tech manufacturing and tobacco. Unsurprisingly, firms in medical and biotech research have also outperformed the market (falling by $16 \%$ relative to the overall fall of $35 \%$ ). Instead, big changes in share prices occurred from the end of February, in the days following Italy's introduction of a lockdown in Lombardy, with very little change in prices in the period before. The exceptions to this are the gas and water, automotive and parts, and fossil fuel production sectors, where changes in share prices took place steadily over the three-month period, possibly driven by other factors.

Tourism and leisure (excluding air travel) sector stands out in being one of the hardest hit industries (in terms of seeing a large reduction in relative share price) and having a relatively high share of protection. As the shutdown continues, more capital-intensive firms that are not able to substantially reduce their costs may start to struggle more; this may lead to pressure for further government support. There are likely to be long-run costs to the economy if these firms were forced to shut down and the skills and experience of their workers were lost [17].

\section{Data and Methodology}

Secondary data used for; share price as a dependent variable and number of confirmed cases of COVID-19 as an independent variable. The study period is starting from the first day announcement of COVID-19 in Malaysia, that is 24th January 2020 up to 30th August 2020. The data were gathered from companies' website and Bursa Malaysia Bloomberg for all the daily share price among 13 sectors captured 913 listed companies (see figure 2). The sector of the company was segregated into two panel data, A and B. Panel A refers to the sectors which are most probably affected by COVID-19 as mentioned by analyst in the literature review such as hotels, airlines, services, transportation and many more. Otherwise, Panel B refers to the active companies even though during COVID-19 for instance; pharmaceutical and medical, gas and water, utilities, consumer products and others. The study also validates the panel segregation by run robust regression to all the observations to identify the affected and not affected sectors based on their share price performance.

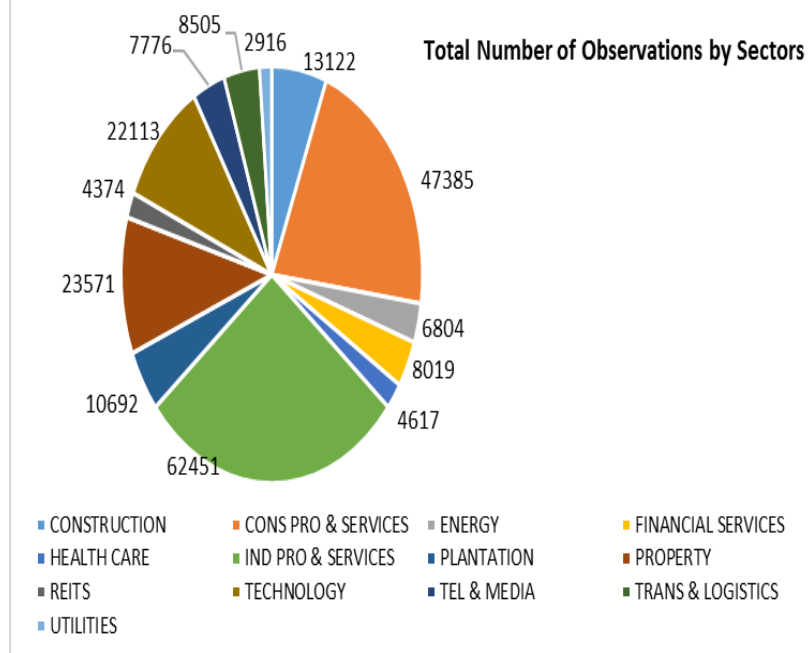

Figure 2: The Number of Observations for the Company in each Sectors

In order to investigate the relationship between share price with number of confirmed case of COVID-19 among sectors in Malaysia, Hausman Test was performed to identify the most appropriate model should be used in making concluding remarks in explaining the relationship between COVID-19 cases with share price. Then, the diagnostic check test was performed on the model selection whereby the modified Wald-chi test for groupwise heteroskedasticity are tested either the variances are constant or not. The significant of probability chi-squared result conclude that there is a heteroskedasticity (variances are not constant) problem. Hence, the most appropriate model is determined based on the significant level of heterokedasticity results. If the chi-squared shows a significant result, then robust multiple regression estimations are required to perform on the selected model and if insignificant the robustness is not required to that level. In this situation, the regression model will run using robust standard errors estimation to overcome or rectify the problem. As benefit of using the Stata, robustness check and test are performed to resolve the problem. 
Table 1: Dependent and Independent Variables

\begin{tabular}{|l|l|}
\hline Variables & Proxies \\
\hline Share Price & $\begin{array}{l}\text { Daily closing price of the listed } \\
\text { company The compary will be } \\
\text { segregated into two panel data, A and B. } \\
\text { Panel A refers to the sectors most } \\
\text { probably affected by COVID-19 as } \\
\text { mentioned by analyst in the literature } \\
\text { review such as hotels, airlines, services, } \\
\text { transportation etc. Otherwise, Panel B } \\
\text { refers to the active companies even } \\
\text { though during COVID-19 for instance; } \\
\text { pharmaceutical products, gas and water, } \\
\text { utilities, consumer products and others. } \\
\text { We validate the segregation of the } \\
\text { sectors in the panel using robust } \\
\text { regression model. }\end{array}$ \\
\hline Independent \\
COVID-19 \\
$\begin{array}{l}\text { Number of confirmed cases by Ministry } \\
\text { of Health in Malaysia in daily basis. }\end{array}$ \\
\hline
\end{tabular}

This research study tested the reaction of share price towards number of COVID-19 cases by investigate the relationship between share price and COVID-19 using multiple regression approach. Thus, robust regression model will be applied to tackle the dynamic changes in price of stock since the movement is based on daily basis.

The multiple regression for such relationship is represented by the four model equations as follows:

SPit $=\alpha+$ COVID-19it + eit

SPit $=\alpha+$ COVID-19it + eit, re

OLS Model (1)

SPit $=\alpha+$ COVID-19it + eit,$f e$

RE Model(2)

FE Model(3)

SPit $=\alpha+$ COVID-19it $+\varepsilon i t$, re Robust Robust RE Model(4) where SP stands for share Price, the time period is denoted by the subscript $\mathrm{t}(\mathrm{t}=1, \ldots, \mathrm{T}=131,043)$; sectors are denoted by the subscript $\mathrm{i}(\mathrm{i}=1, \ldots, \mathrm{N}=13$ sectors, 913 companies); $\alpha$ represents constant term; and cit is the random error term.

Theoretically, a stock price takes into account all available information and expectations about the future. So a stock's price is equal to its current price plus the summation of its expected future dividends.

\section{Results and Discussion}

\section{A. Descriptive Statistics}

With respect to the descriptive statistics result as presented in Table 2, the total number of observations used in this study for panel A and B is $\mathrm{N}=191,727$ and 30,618 daily announcement news bases respectively for both variables proxies either share price or COVID cases. The mean for share price is at RM0.822 and RM1.97 for panel A and B respectively. As for COVID cases is around 39 and 55 cases for panel $\mathrm{A}$ and $\mathrm{B}$ respectively. Whereas, the maximum value of this variable is RM147.50 and RM 28.40 and 277 cases for panel A and B respectively indicated that the stock price is still performed better in average for most of the sectors even though the number of cases is increasing pattern in Malaysia.
Table 2: Results of Descriptive Statistics

\begin{tabular}{|l|l|l|l|l|l|}
\hline \multirow{2}{*}{ Variable } & \multicolumn{5}{|l|}{ Panel A } \\
\cline { 2 - 6 } & N & Mean & SD & Min & Max \\
\hline Sector & 191,727 & 5.739 & 3.296 & 1 & 12 \\
\hline Date & 191,727 & 22,037 & 70.15 & 21,916 & 22,158 \\
\hline Price & 191,727 & 0.822 & 4.793 & 0 & 147.5 \\
\hline CovidCase & 191,727 & 38.55 & 55.42 & 0 & 277 \\
\hline LnPrice & 112,348 & -0.849 & 1.389 & -5.298 & 4.994 \\
\hline \multirow{2}{*}{ Variable } & Panel B & \multicolumn{5}{|l}{} \\
\cline { 2 - 6 } & N & Mean & SD & Min & Max \\
\hline Sector & 30,618 & 6.77 & 2.628 & 4 & 13 \\
\hline Date & 30,618 & 22,037 & 70.15 & 21,916 & 22,158 \\
\hline Price & 30,618 & 1.97 & 3.961 & 0 & 28.4 \\
\hline CovidCase & 30,618 & 38.55 & 55.42 & 0 & 277 \\
\hline LnPrice & 18,695 & 0.325 & 1.327 & -3.689 & 3.346 \\
\hline
\end{tabular}

\section{B. Regression Analysis}

The study was considered all 13 sectors with 913 listed companies traded in Bursa Malaysia for instance, construction, consumer product and services, energy, financial services, health care, industrial products \& services, plantation, property, real estate investment trusts (REITs), technology, telecommunication \& media, transportation \& logistic and utilities sector. All these sectors were analyzing by using robust regression in order to segregate into two panel, A and B (see Table 3, the panel was indicated in bracket).

Based on results presented in Table 4, unbalanced panel data are applied for the tests since panel A and B indicate unequal number of observations, $\mathrm{N}$ which cover the pooled ordinary least square (OLS), fixed effects (FE) and random effects (RE) models. The diagnostic check test was performed on the model selection whereby the modified Wald-chi test for groupwise heteroskedasticity are tested either the variances are constant or not. The significant of probability chi-squared result conclude that there is a heteroskedasticity (variances are not constant) problem. Hence, the most appropriate model is determined based on the significant level of heterokedasticity results. If the chisquared shows a significant result (in this case both panel A and B indicate a significant at 99 percent confident level for all models), then robust multiple regression estimations are required to perform on the selected model and if insignificant the robustness is not required to that level. In this situation, the regression model will run using robust standard errors estimation to overcome or rectify the problem. As benefit of using the Stata, robustness check and test are performed to resolve the problem. Besides, the study revalidates the result with Hausman diagnostic tests to determine which models i.e; RE or FE, is the best-fit and most appropriate model in explaining the relationship between COVID-19 cases and share price with heterokedasticity problem. The Hausman test results (panel $\mathrm{A}$ at -0.28 and $\mathrm{B}$ at 0.000 which is both are insignificant) shown that RE is the most appropriate model to explain such relationship 
Table 3: Segregation of the Sectors into Panel, A or B

\begin{tabular}{|c|c|}
\hline Variable/ Sector & $\begin{array}{l}\text { Robust } \\
\text { Model }\end{array}$ \\
\hline COVID Cases & $\begin{array}{l}-0.00211 * * * \\
-1.157 * * *\end{array}$ \\
\hline Construction & (A) \\
\hline Consumer Products \& Services & $-0.892 * *(\mathrm{~A})$ \\
\hline Energy & $-1.413 * * *(\mathrm{~A})$ \\
\hline Financial Services & $0.213(\mathrm{~B})$ \\
\hline Health Care & $0.0372(\mathrm{~B})$ \\
\hline Industrial Products \& Services & $-1.146 * * *(\mathrm{~A})$ \\
\hline Plantation & $-0.16(\mathrm{~B})$ \\
\hline Property & $-1.259 * * *(\mathrm{~A})$ \\
\hline Real Estate Investment Trusts & $-0.228(\mathrm{~B})$ \\
\hline Technology & $-1.676 * * *(\mathrm{~A})$ \\
\hline Telecommunications \& Media & $-1.464 * * *(\mathrm{~A})$ \\
\hline Transportation \& Logistics & $-1.097 * *(\mathrm{~A})$ \\
\hline Utilities & $-(\mathrm{B})$ \\
\hline Constant & 0.406 \\
\hline Observations & 131,043 \\
\hline Number of Stock Name \& Code & 913 \\
\hline R square & 0.1876 \\
\hline Wald chi square & $2180.65 * * *$ \\
\hline Sector RE & Yes \\
\hline
\end{tabular}

\section{Note: Robust standard errors in}

parentheses $* * * \mathrm{p}<0.01$, ** $\mathrm{p}<0.05$

In addition to that, R-square is reported for the model estimation of regression in order to investigate the percentage of relationship from the number of COVID-19 cases as explanatory variation in explaining the share price. The robust RE result also reveals the satisfactory and acceptable value of R-square for about 20.04 percent for panel A and 11.42 percent for panel B. These implies that share price under panel A sectors have about 20.04 percent affected by the COVID-19 cases which is higher than sectorial from panel B as for 11.42 percent.

In Overall, the finding shows that sectors' share price are significant at 99 percent confident level and have a negative relationship towards the number of COVID cases either panel A or B. However, the momentous impact of COVID19 can be seen quite affected in certain sectors for instance, construction, consumer product and services, energy, industrial products \& services, property, technology, telecommunication \& media and transportation \& logistic sector with all indicate negatively association (supported by results in Table 2). Meaning that, the higher the number of COVID cases, the lower the share price performance. Thus, this study justifying that there is a negative reaction and significant relationship between share price and COVID cases.
Table 4: Results of Random Effect Robust Regression

\begin{tabular}{|c|c|c|c|c|}
\hline \multirow[b]{2}{*}{$\begin{array}{l}\text { Variabl } \\
\text { e }\end{array}$} & \multicolumn{4}{|l|}{ Panel A } \\
\hline & OLS & $\begin{array}{l}\text { RE } \\
\text { Model }\end{array}$ & $\begin{array}{l}\text { FE } \\
\text { Model }\end{array}$ & $\begin{array}{l}\text { RE } \\
\text { Robust } \\
\text { Model } \\
\end{array}$ \\
\hline \multirow[t]{2}{*}{$\begin{array}{l}\text { Covid } \\
\text { Case }\end{array}$} & $\begin{array}{l}- \\
0.0021 * * \\
*\end{array}$ & $\begin{array}{l}- \\
0.0022 * * \\
*\end{array}$ & $\begin{array}{l}- \\
0.0022 * * \\
*\end{array}$ & $\begin{array}{l}- \\
0.0022 * * \\
*\end{array}$ \\
\hline & $-7.48 \mathrm{e}-05$ & $\begin{array}{l}-1.32 \mathrm{e}- \\
05\end{array}$ & $-1.32 \mathrm{e}-05$ & $-5.05 e-05$ \\
\hline \multirow[t]{2}{*}{ Constant } & $\begin{array}{l}- \\
0.772 * * *\end{array}$ & $\begin{array}{l}- \\
0.769 * * *\end{array}$ & $0.767 * * *$ & $-0.769 * * *$ \\
\hline & -0.00497 & -0.0471 & $\begin{array}{l}- \\
0.000879\end{array}$ & -0.0464 \\
\hline $\begin{array}{l}\text { Random } \\
\text { Effect }\end{array}$ & & Yes & & Yes \\
\hline $\begin{array}{l}\text { Fixed } \\
\text { Effect }\end{array}$ & & & Yes & \\
\hline R Square & 0.007 & 0.2004 & 0.2004 & 0.2004 \\
\hline $\begin{array}{l}\text { Wald } \\
\text { Chi }\end{array}$ & & $\begin{array}{l}27961.61 \\
* * *\end{array}$ & & $\begin{array}{l}1926.38 * \\
* *\end{array}$ \\
\hline $\begin{array}{l}\text { Hausma } \\
\mathrm{n} \text { Test }\end{array}$ & & -0.28 & & \\
\hline $\begin{array}{l}\text { Heterosk } \\
\text { e- } \\
\text { dasticity }\end{array}$ & \multicolumn{4}{|c|}{$2.9 \mathrm{e}+33 * * *$} \\
\hline \multirow[b]{2}{*}{$\begin{array}{l}\text { Variabl } \\
\text { e }\end{array}$} & \multicolumn{4}{|l|}{ Panel A } \\
\hline & OLS & $\begin{array}{l}\text { RE } \\
\text { Model }\end{array}$ & $\begin{array}{l}\text { FE } \\
\text { Model }\end{array}$ & $\begin{array}{l}\text { RE } \\
\text { Robust } \\
\text { Model } \\
\end{array}$ \\
\hline \multirow[t]{2}{*}{$\begin{array}{l}\text { Covid } \\
\text { Case }\end{array}$} & $\begin{array}{l}- \\
0.0014 * * \\
*\end{array}$ & $\begin{array}{l}- \\
0.0015^{* *} \\
*\end{array}$ & $\begin{array}{l}- \\
0.0015^{* *} \\
*\end{array}$ & $\begin{array}{l}- \\
0.0015^{* *} \\
*\end{array}$ \\
\hline & 0.000175 & $3.00 \mathrm{e}-05$ & $3.00 \mathrm{e}-05$ & $9.82 \mathrm{e}-05$ \\
\hline \multirow[t]{2}{*}{ Constant } & $0.378^{* * *}$ & $0.355^{* * *}$ & $0.379 * * *$ & $0.355^{* * *}$ \\
\hline & 0.0117 & 0.116 & 0.002 & 0.114 \\
\hline $\begin{array}{l}\text { Random } \\
\text { Effect }\end{array}$ & & Yes & & Yes \\
\hline $\begin{array}{l}\text { Fixed } \\
\text { Effect }\end{array}$ & & & Yes & \\
\hline R Square & 0.004 & 0.1142 & 0.1142 & 0.1142 \\
\hline $\begin{array}{l}\text { Wald } \\
\text { Chi } \\
\end{array}$ & & $\begin{array}{l}2393.84 * \\
* *\end{array}$ & & $\begin{array}{l}222.61 * * \\
*\end{array}$ \\
\hline $\begin{array}{l}\text { Hausma } \\
\mathrm{n} \text { Test }\end{array}$ & & 0.000 & & \\
\hline $\begin{array}{l}\text { Heterosk } \\
\text { e- } \\
\text { dasticity }\end{array}$ & \multicolumn{4}{|c|}{$1.5 \mathrm{e}+05^{* * *}$} \\
\hline
\end{tabular}

\section{Discussion And Conclusion}

The study provides a practical outcome to a government and stock market player (i.e; Bursa Malaysia and Securities Commissions) as well as stakeholders particularly for the future strategize planning while facing with any pandemic event that most probably will be happened again and again. Besides, the findings benefited stakeholders where, be able to provide justifications, by considering the risk and 
opportunities (possible gain in abnormal returns) in trading market, be able to forecast the movement of share price by identifying its significant reaction to certain sectors, and be able to make recommendations and provide inputs to government on risks and opportunities in business performance. An evaluation and comparison of share price volatility across the sectors of the companies listed in Main market of Bursa Malaysia also can further predicted. By segregating the companies into diversify sectors, it can help the policymaker to estimate the market performance during COVID 19 or any future pandemic spreads if happen to the respective business sector based on share price. A robust analysis, which involve a random effect of relationship between share price and COVID-19 cases variables as explained shown a negatively significant relationship in overall. This shows that most of the sectors are affected in their share price performance to worst level even some of them still outperformed. Therefore, again the outcome from this study are beneficial to market player in developing a strategy for buying, selling or hold position for share price movement pattern based on event study approach that can help the policy makers (Government, Bursa Malaysia, Securities Commission, etc) and investors (domestic and foreigner) as guidelines with respect to specific practices/action to be taken that would require more deliberation to secure their future investment in main market in Malaysia. Besides, this study can provide a reference to stakeholders on the significant association between share price and COVID-19 pandemic spreads in Malaysia

\section{References}

[1] Say T.L (2020), Bursa Malaysia getting feedback on shorter trading hours Market, The Star, 1st April 2020.

[2] Yusof, A (2020). Coronavirus may bug Bursa, other emerging markets". New Straits Times. (30 January 2020). Archived from the original on 23 February 2020. Retrieved 22 February 2020.

[3] Ralph, J (2020)"Coronavirus Strikes Tourism, Factories, Consumption around Southeast Asia". Voice of America. (12 February 2020). Archived from the original on 22 February 2020. Retrieved 22 February 2020.

[4] Alifah Z \& Hussein S (20 February 2020). "Prolonged Covid-19 may hit Malaysia's GDP hard". The Malaysian Reserve. Archived from the original on 21 February 2020. Retrieved 22 February 2020.

[5] D'Silva, V. (17 February 2020). "Johor tourism sector suffers severe Covid-19 fallout, seeks govt help". New Straits
Times. Archived from the original on 22 February 2020. Retrieved 22 February 2020. (D'Silva, 2020),

[6] Aziz, A\& Naharul, M.A (14 February 2020). "Melaka's tourist footfall drops, thousands of bookings cancelled". The Malaysian Reserve. Archived from the original on 22 February 2020. Retrieved 22 February 2020 (Sekaran, 2020)

[7] Sekaran, R. (11 February 2020). "Penang tourism feeling the effects". The Star. Archived from the original on 22 February 2020. Retrieved 22 February 2020.

[8] Bedi, S., \& Rashvinjeet (13 February 2020). "Covid-19: Malaysia eyeing Asean market due to shortfall of Chinese tourists". The Star. Archived from the original on 22 February 2020. Retrieved 22 February 2020

[9] Kanyakumari, D (14 February 2020). "Malaysian states to consider pivot towards domestic tourism amid COVID19 outbreak". CNA. Archived from the original on 22 February 2020. Retrieved 22 February 2020.

[10] Solhi, F (26 January 2020). "Some Malaysians calling for ban on Chinese tourists". New Straits Times. Archived from the original on 23 February 2020. Retrieved 23 February 2020.

[11] Dzulkifly, D (13 March 2020). "Muhyiddin: Tourism industry hit hardest by Covid-19, faces RM3.37b loss". The Malay Mail. Archived from the original on 14 March 2020. Retrieved 14 March2020.

[12] Eustance H \& Yen N.L. (26 February 2020). "Malaysian ringgit set to weaken further as political chaos and coronavirus take hold, says Aberdeen". CNBC. Archived from the original on 28 February 2020. Retrieved 26 February 2020.

[13] He, P., Sun Y., \& Zhang Y., ORCID Icon \&Tao Li (2020). COVID-19's Impact on Stock Prices Across Different SectorsAn Event Study Based on the Chinese Stock Market, Emerging Markets Finance and Trade, Volume 56, 2020 - Issue 10: Special Issue: Research on Pandemics, 
Pages 2198-2212 | Published online: 25 Jul 2020

[14] Anh, D.L.T. and Gan, C. (2020), "The impact of the COVID-19 lockdown on stock market performance: evidence from Vietnam", Journal of Economic Studies, Vol. ahead-of-print No. ahead-of-print. https://doi.org/10.1108/JES-06-2020-0312.

[15] Štifanić, D. Musulin, J., Miočević, A., Šegota, S.B.,Šubić, R. \& Car, A., "Impact of COVID-19 on Forecasting Stock Prices: An Integration of Stationary Wavelet Transform and Bidirectional Long ShortTerm Memory", Complexity, vol. 2020, Article ID 1846926, 12 pages, 2020. https://doi.org/10.1155/2020/1846926

[16] Niels Joachim, G., \&Koijen.R 'Coronavirus: Impact on Stock Prices and Growth Expectations'. Becker Friedman Institute for Economics WP 2020-22, 24 March 2020.

[17] Stefano,R.,\& Wagne,W (2020) 'What the stock market tells us about the consequences of COVID-19'. VoxEU, https://voxeu.org/article/what-stockmarket-tells-us-about-consequences-covid19, 12 March 2020

\section{Authors Profile}

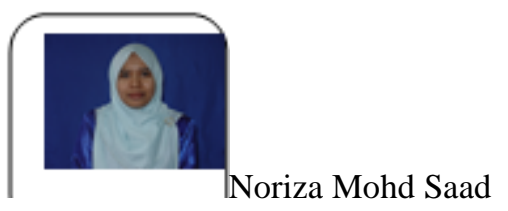

She is a senior lecturer in the Accounting \& Finance Department at Universiti Tenaga Nasional since 2002. Hold a position as a Head of Department for 4 years from 2012 until 2016 and prior to that, as a Head of unit for finance and Program Coordinator for MSc in Finance. She teaches finance subjects such as derivatives market, Islamic capital market, investment, corporate finance and risk management and insurance. She obtained her Bachelor of Finance (Hons) from Universiti Teknologi MARA in 2001, MBA from Universiti Utara Malaysia in 2002 and graduated from Universiti Teknologi MARA in 2017 with a Ph.D in Accountancy. Her areas of research are Islamic capital market, corporate governance, capital structure, business financial performance, tariff optimization and sukuk market. She has published book, Introduction to Finance by Pearson, won 3 silver and 2 bronze awards from exhibitions and presented more than 100 articles in international and national high impact journals and conferences including 12 for ERA, 6 for SCOPUS and 12 for ISI (where one out of 12 is Q1 (Elsevier- Pacific Basin Finance Journal). Currently, she actively involved in consultancy and external research grant for instance from Tenaga Nasional Berhad as well as Energy Commission of Malaysia.

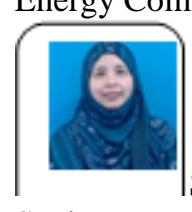

Senior Lecturer at (UNITEN) with rich experience of more than 10 years in academia. Her research areas include financial management and Islamic finance. She can be reached at Noredi@uniten.edu.my 